\title{
A SUPPORTIVE LEARNING ENVIRONMENT, THE CREATION OF IT AS AN EDUCATIONAL FACTOR: AN ANALYSIS OF TEACHERS’ AND STUDENTS' ATTITUDE
}

\author{
Birutė Jatkauskienė \\ Rūta Marija Andriekienè \\ Modestas Nugaras \\ Klaipèda University, Lithuania
}

\begin{abstract}
This article presents a study, an analysis of teachers' and students' attitude toward the concept of a learning environment, elements of the development of it, the accountability for creating a supportive learning environment, by revealing an educational effect of it on student relationships and on outcomes of studies and learning. The research is aimed to answer the main problematic question: how do teachers and students perceive a learning environment, its elements, the creation, accountability for a supportive learning environment, what kind of educational effect may it have? The article consists of an introduction, study design, research results, conclusions, and references. The empirical study shows that teachers and students have quite a clear understanding of the concept of a learning environment, however, both groups under study (teachers and students) construe various learning environments, elements of their creation, accountability of actors for creating and maintaining the environments in a different way. In spite of some differences in attitudes of teachers and students, both groups of respondents acknowledge the fact that a learning environment has an educational effect on interrelationships of students, outcomes of learning and studies. It has to be assumed that observations made in this research can be used in the teaching practice so as to better understand contemporary students, relationships between teachers and students, as well as the formation of students' positive attitudes toward learning activities and communication.
\end{abstract}

Keywords: learning environment, its elements, creation, interpersonal relations of students.

\section{Introduction}

Thinking about a man of today in a learning society, adult education, lifelong learning, and studies, we often have to deal with a concept of a learning environment, or, a supportive learning environment. This concept is common among scholars, practitioners, and politicians. In particular, when it comes to the quality of studies, learning, education, outcomes, results of learning. However, authors are forced to acknowledge that there sometimes a misunderstanding 
occurs, since the concept of a learning environment is multidimensional, which complicates communication among education theorists, practitioners, politicians, teachers, and students. It has to be assumed that the concept of a learning environment came into use of spoken language before it was theoretically grounded. This phenomenon has created a certain semantic confusion in our communication. This has been an inducement to the author of the article to go deep into the concept and to launch this research. The goal of research is to analyse an attitude of teachers and students toward the concept of a learning environment, elements of its development, accountability for creating a supportive learning environment, through revealing its educational effect on interpersonal relationships of students, outcomes of studies and learning.

Though scientific literature does not provide an unambiguous answer to what a learning environment is, it always emphasises its significant role in quality learning and interpersonal relationships. There can be certain matching observed in various definitions of the concept of a learning environment:

- A learning environment is defined as a place or a space in which learning occurs (Trakšelys \& Martišauskienè, 2013; Mozalta, 2017; Lipinskienè, 2002; Blandin, 2008; Bullard, 2016; Brazdeikis, 2009 et al.);

- A learning environment is a dynamic interaction of four factors: a learner (who?), a teacher or other educational specialists (with whom?), a content of learning (what do they learn?), facilities and technology (where, by means of what?). besides, thus interaction implies various learning theories used by practitioners, as well as their educational activities (Dumont, Istance, \& Benavides, 2010; Tolutienè, 2013; Dumont, Istance, \& Benavides, 2010; Jatkauskienė, Andriekienè, \& Trakšelys, 2014, et al.);

- A learning environment consists of three main aspects: a) learning goals, b) the division of teacher and learner roles, and c) the roles of the learners in relation to each other and a school culture (De Kock, Sleegers, \& Voeten, 2004; Jensen, 2001; Lipinskiene, 2002; Brazdeikis, 2009; Tuit, Haynes, Stewart, \& Patton, 2016; Joseph, Haynes, \& Cobb, 2015, etc.);

- A learning environment has certain dimensions: a learner's (micro) level, an organization's (mezzo) level, and a country's (macro) level (Blandin, 2008; Jatkauskienè \& Andriekienè, 2013, et al.);

- A learning environment can be of different types: educational, psychological, material, physical, intellectual (Jucevičienė, 2010; Lipinskienè, 2002; Fisher, Frey, Quaglia, Smith, \& Lande, 2017; Grigaliūnaite, 2002; Kuklauskas \& Kuklauskienè, 2012; Starnge \& 
Banning, 2015; Nilson \& Goodson, 2017; Hung \& Zhang, 2008, et al.)

- An emphasis in the learning environment is placed on activities that allow constructing the understanding and developing the skills necessary to solve various learning problems (Barkauskaite \& Motiejūnienė, 2004; Kišonienė \& Dudzinskienė, 2007; Bullard, 2016, et al.);

- There are supportive or unsupportive learning environments (Jatkauskienè \& Andriekienè, 2014, etc.). A supportive learning environment is a conditionally stable and typical emotional state, which is formed in members of an organisation while working and collaborating (Guščinskienè, 2009: p. 158).

As a brief review of the literature suggests, the problem of a learning environment is increasingly being analysed from a scientific point of view. That is understandable - while an attitude toward learning, its goals, content, technologies, subject of learning, object, etc. is changing, an attitude toward an environment in which a learning process takes place should change, too. On the other hand, a learning environment is increasingly being argued to be enabling. In this context, the enabling is understood as a process in which people or communities develop their ability to manage their lives and to address important issues in their lives. Therefore, it is natural that the modern learning environment of a university should be of not less concern than other components of the didactic system.

Implementation of the concept of lifelong learning stimulates not only individual but a group learning as well. In this connection, relationships between a group of learners and aspects of harmonisation thereof emerge. An analysis of scientific literature on the concept of a learning environment allows suggesting that that there is a direct relationship between an environment supportive for learning and interpersonal relations of the group of learners, as some authors argue. The researchers of harmonisation of mutual relations and elements of a supportive learning environment, such as: D. Jonassen, S. Land, M. Thomas (2012), C. C. Strange, J. H. Bannig (2015), F. Tuitt, C. Haynes, S. Steward (2016) et al., emphasise that learning is a dialogue, a community that is important for achievements of students, while a developed learning environment, supportive for the harmonisation of interpersonal relationships, is an intellectual and social development of learners. Thus, the following hypothesis is suggested in this study: a supportive learning environment, the creation of it can be one of the main educational factors for the harmonisation of mutual relations in the group of learners and for the outcomes of studies and learning. The following main problematic question has been raised in order to verify the hypothesis: how do teachers and students perceive a learning 
environment, its elements, the creation, accountability for a supportive learning environment, what kind of educational effect may it have?

To answer the above problematic question, a number of partial questions have been framed as follows:

1. What is the attitude of teachers and students toward the concept of a supportive learning environment and does it differ?

2. What is the attitude of teachers and students toward the accountability for creating and maintaining a supportive learning environment and how does it differ?

3. What is the attitude of teachers and students toward the elements of developing a supportive learning environment and how does it differ?

4. What is the attitude of teachers and students toward mutual relations and harmonisation thereof in the creation of a supportive learning environment, how does it differ?

Respectively and in accordance with the partial questions, findings are presented below.

Theoretical and practical implications of the research: the authors found no previous studies that would reveal teachers' and students' perception of learning environments, the creation of them and the educational effect there of on student relationships, outcomes of learning and study. The findings of the research might presumably be used as specific recommendations for improving teachers' didactic practices, ensuring more effective internal and external communication, better understanding of contemporary students, their learning needs, etc.

\section{Study Design}

Based on the ideas of the supportive learning environment and harmonisation of learners' mutual relations, that more pronounced during the review of the scientific literature, the following theoretical and methodological provisions were taken into consideration when designing the empirical research:

- $\quad$ European liberal education paradigm, where learning is construed as an assistance for learners in their self-actualisation and self-fulfilment processes, a primary focus on a personality, on the intense development of a person's basic skills and competences, and on the training of a professional for work activities;

- A human learning theory as the most appropriate formulation of the liberal education paradigm. This theory emphasises the integrity of each person necessary for fulfilling oneself as a personality (Rogers, 1969), in particular, for the self-actualization of personal potential 
(Maslow, 1962). The key principle of the theory is a human's pursuit to realise oneself in full and to assume responsibility for personal development;

- $\quad$ positivist epistemology of empirical research, characterised by the belief that a social phenomenon can be empirically studied on the basis of partially known facts, by suggesting hypotheses about the interrelation of such facts, which are thereafter subject to verification, validation or disproval (Rupšienè \& Rutkienè, 2016).

The study has been conducted in two phases. The first phase took place in 2016-2017 and involved the analysis of scientific literature, written questionnaire of teachers of educology, andragogy study programmes $(n=168)$ in Lithuanian universities (Klaipeda University, Šiauliai University, Vytautas Magnus University, Lithuanian University of Educational Sciences, Vilnius University, Kaunas University of Technology) (total number of academic staff in educology and andragogy study programmes is about 440 persons with Doctoral and Master's degrees in social sciences) in order to find out: their attitude toward the concept of a supportive learning environment, individuals accountable for the creation of supportive learning environments, the elements of developing such environments, educational effect of the learning environments on studies, learning process and the harmonisation of interpersonal relations. The second phase of the study was held in 2017 by using the same survey tools and involved a survey of students of the first and second degree in educology and andragogy study programmes of Lithuanian universities $(n=273)$. Such a statistical population is based on the authors' belief that prospective educators and andragogues should be well aware of what a learning environment means. According to the data provided by the Ministry of Education and Science of Lithuania on 1 October 2017, a total of 824 future educators and andragogues studied at Lithuanian universities who took part the first and second phases of the research. A sample size was determined in accordance to the formula $n=1 /(\Delta 2+1 / N)$, where $n$ is a sample volume, $N$ population size, $\Delta$-error (5-10\% is advisable). Upon applying the error, the sample volume selected ( $\mathrm{n}=273$, a group of students) and $(\mathrm{n}=168$, a group of teachers) is considered as appropriate. The completed questionnaires show that $89 \%$ of female took part in the survey. The group of teachers was mostly made up of people between the ages of 45 and 55 . The average age of the student group was 24 years old. The survey tool, questionnaire, was developed by the authors based on the supportive learning environment parameters, that were established in the process of analysing the scientific literature, as well as the ideas for harmonisation of relations within a group. So as to measure elements of a supportive learning environment, the creation thereof as an educational 
factor for the harmonisation of relationships within the student group, rank and nominal measuring scales have been applied. The obtained data was analysed by means of the SPSS platform (version 20) through statistical methods of data analysis: descriptive statistics, parametric and nonparametric criteria for assessing differences between teacher and student groups, whereby substantial differences between the estimates of the two groups of survey were identified. They are presented in the following sections of the article.

\section{Results of the Research and Discussion}

\section{The attitude of teachers and students toward the concept of a supportive learning environment}

The first question of research: What is the attitude of teachers and students toward the concept of a supportive learning environment and does it differ? Given the fact that a supportive learning environment is defined as a multidimensional object, there are several learning environments: educational, psychological, material (physical), and intellectual, exactly whereat differences in the attitudes of teachers and students were sought. Respectively and based on the above different learning environments (educational, psychological, material (physical), intellectual) findings of the research are herby presented.

1.1. Differences in the attitude toward the concept of an educational learning environment

According to P. Jucevičiene (2010), it is worthwhile today fostering a dialogue of perceptible learning environments that have quite a diverse potential to transform into learning environments that are specific to a certain kind of individuals and which are built by teachers or andragogues. There are natural or artificial educational learning environments. The above author lists the following dimensions of the educational environment: learners' interrelationships, commitment to learning, workload, and learning methods. It was, therefore, important to find out how respondents understood the educational aspect of a learning environment.

By applying the Kruskal-Wallis test, the following statistically significant differences in the teachers' and students' perception of educational environment have been identified: 
SOCIETY. INTEGRATION. EDUCATION

Proceedings of the International Scientific Conference. Volume I, May $25^{\text {th }}-26^{\text {th }}$, 2018. 168-185

Table 1 Differences in the teachers' and students' attitude toward the concept of an educational environment

\begin{tabular}{|c|c|c|c|}
\hline Variables of educational environment & Group & $\begin{array}{l}\text { Average } \\
\text { ranks }\end{array}$ & test results \\
\hline \multirow{2}{*}{$\begin{array}{l}\text { Educational environment is a totality of } \\
\text { teacher-student relations }\end{array}$} & Students & 177 & \multirow{2}{*}{$\begin{array}{l}\chi 2=8.891 ; \\
d f=2 ; p=0.012\end{array}$} \\
\hline & Teachers & 219 & \\
\hline \multirow{2}{*}{$\begin{array}{l}\text { Educational environment is a space } \\
\text { perceptible to learning }\end{array}$} & Students & 181 & \multirow[b]{2}{*}{$\begin{array}{l}\chi 2=11.335 \\
d f=2 ; p=0.003\end{array}$} \\
\hline & Teachers & $\overline{222.2}$ & \\
\hline \multirow{2}{*}{$\begin{array}{l}\text { Educational environment is an } \\
\text { informational space created by the teacher }\end{array}$} & Stude & 236 & \multirow[b]{2}{*}{$\begin{array}{l}\chi 2=19.355 \\
d f=2 ; p=0.000\end{array}$} \\
\hline & Teachers & 189.06 & \\
\hline \multirow{2}{*}{$\begin{array}{l}\text { Educational environment is a place } \\
\text { comprising physical and social aspects of } \\
\text { learning }\end{array}$} & Stude & 180 & \multirow[b]{2}{*}{$\begin{array}{l}\chi 2=1.112 \\
\mathrm{df}=2 ; p=0.573\end{array}$} \\
\hline & Teac & $\overline{196}$ & \\
\hline \multirow{2}{*}{$\begin{array}{l}\text { Educational environment is a place where } \\
\text { students work together and support each } \\
\text { other }\end{array}$} & Studen & 213.59 & \multirow[b]{2}{*}{$\begin{array}{l}\chi 2=6.537 ; \\
d f=2 ; p=0.038\end{array}$} \\
\hline & Teachers & 211.18 & \\
\hline
\end{tabular}

The table above shows that there are statistically significant differences between the teachers' and students' attitude toward the concept of an educational environment in some aspects. Teachers place more emphasis on the educational environment as the totality of relationships between teachers and students (average rank - 219), as a space perceptible to learning (average rank 222), while students rather agree with the statement that an educational environment is an informational space created by the teacher (average rank 236.01). The smallest differences are attributed to the last statement (an educational space is a place where students work together and support each other). This statement can become a prerequisite for harmonisation of student interrelationships.

Based on previous studies (Blandin, 2008; Brazdeikis, 2009, et al.), an educational environment enables personal self-learning, provides a greater opportunity to develop individual learning, communication, and interpersonal relationships. That is perhaps why academic staff stresses in the survey that an educational environment is a totality of teacher-student relations, a space perceptible to learning where not only positive relationships are built, but an appropriate learning culture is fostered, as well.

1.2. Differences in the attitude toward the concept of a psychological learning environment

Human relationships are one of the most crucial aspects in different life situations. People interact with each other to receive or transmit certain information; their success in it depends on whether results of conversation, 
discussion are positive and whether they understand each other. In a higher school, such interaction and the relation between a teacher and a student are very important, as influencing the perception of the information being transmitted, getting the help needed, psychological and spiritual balance.

A psychologically friendly learning environment can be described as collaboration between a teacher and learners, whereby a sense of safety, value, and understanding is assured (Eggen \& Kauchak, 2013). It is important for a class to have a sense of tolerance and to live as a small, cohesive community in which everyone has self-esteem and develops their ability to learn and improve. According to the authors, an appropriate psychological environment facilitates constructive problem solving, reveals the personality of a teacher and a learner, motivates to learn, develops life skills and, in general, allows to prevent lots of problems. Many authors (Mercer et al., 2011; Muy \& Reynolds, 2011; Eggen \& Kauchak, 2013), argue that a teacher plays the most important and decisive role in creating a supportive psychological environment. According to Mercer et al. (2011), such attitudes and features of a teacher as good looks, positivity, motivation and support for learners' opinions and position have a tremendous influence on the creation of a positive psychological climate.

Table 2 Differences in the teachers' and students' attitude toward the concept of a psychological learning environment

\begin{tabular}{|c|c|c|c|}
\hline $\begin{array}{c}\text { Variables of psychological learning } \\
\text { environment }\end{array}$ & Group & $\begin{array}{l}\text { Average } \\
\text { ranks }\end{array}$ & $\begin{array}{l}\text { Kruskal-Wallis } \\
\text { test results }\end{array}$ \\
\hline \multirow{2}{*}{$\begin{array}{l}\text { Psychological learning environment is a } \\
\text { continuous communication and } \\
\text { collaboration between a teacher and } \\
\text { students }\end{array}$} & Students & 113.71 & \multirow{2}{*}{$\begin{array}{l}\chi 2=86.089 ; \\
d f=2 ; p=0.000\end{array}$} \\
\hline & Teachers & 222.05 & \\
\hline \multirow{2}{*}{$\begin{array}{l}\text { Psychological learning environment is the } \\
\text { assurance of safety, value, and } \\
\text { understanding }\end{array}$} & Students & 215.59 & \multirow{2}{*}{$\begin{array}{l}\chi 2=49.748 ; \\
d f=2 ; p=0.000\end{array}$} \\
\hline & Teachers & 136.95 & \\
\hline \multirow{2}{*}{$\begin{array}{l}\text { Psychological learning environment is a } \\
\text { prevalence of tolerance, open-mindedness } \\
\text { in learning }\end{array}$} & Students & 202.02 & \multirow{2}{*}{$\begin{array}{l}\chi 2=12.664 ; \\
d f=2 ; p=0.000\end{array}$} \\
\hline & Teachers & $\begin{array}{l}69.99 \\
\end{array}$ & \\
\hline \multirow{2}{*}{$\begin{array}{l}\text { Psychological learning environment is a } \\
\text { positive attitude and focus on the strengths } \\
\text { and capabilities of a student }\end{array}$} & Students & 217.75 & \multirow{2}{*}{$\begin{array}{l}\chi 2=65.364 ; \\
d f=2 ; p=0.000\end{array}$} \\
\hline & Teachers & 121.78 & \\
\hline \multirow{2}{*}{$\begin{array}{l}\text { Psychological learning environment is a } \\
\text { stimulus for a learner's reasoning }\end{array}$} & Students & 138.09 & \multirow{2}{*}{$\begin{array}{l}\chi 2=52.041 ; \\
d f=2 ; p=0.000\end{array}$} \\
\hline & Teachers & 214.63 & \\
\hline $\begin{array}{l}\text { Psychological learning environment is an } \\
\text { adaptation of a teacher's didactic practice } \\
\text { to different learning styles of a student }\end{array}$ & $\begin{array}{l}\text { Students } \\
\text { Teachers }\end{array}$ & $\begin{array}{r}119.78 \\
220.34 \\
\end{array}$ & $\begin{array}{l}\chi 2=80.341 ; \\
d f=2 ; p=0.000\end{array}$ \\
\hline
\end{tabular}


D. Mujis et al. (2011) emphasises that psychological climate is quite a wide-ranging concept encompassing the mood or atmosphere that is created in the teacher's classroom, the way the teacher interacts with students, through the rules set out, a tolerance, attention to each person, his/her needs, interests. A warm and supportive learning environment motivates a learner to make a positive contribution to the lesson, stimulates his/her thinking, ingenuity, curiosity, self-esteem, confidence in oneself and the teacher, enhances a sense of responsibility and creates a positive attitude to learning (Teresevičienè et al., 2003).

This study identifies significant differences in teachers' and students' attitude toward the psychological learning environment. The compared variables of teachers' and students' attitude toward the psychological learning environment allow stating that students perceive a positive psychological environment as the assurance of safety, value, and understanding (average rank - 215.59); as a positive attitude and focus on strengths and capabilities of a student (average rank - 217.75); as a prevalence of tolerance, open-mindedness in learning (average rank - 202.02). Meanwhile, a supportive teaching environment means to teachers, first of all, continuous communication and collaboration between two parties, faculty and students, (average rank - 222.05); and an adaptation of a teacher's didactic practice to different learning styles of students (average rank - 220.34).

1.3. Differences in the attitude toward the concept of a material (physical) learning environment

According to a number of authors (Jensen, 2009; Eggen \& Kauchak, 2013; Mercer et al., 2011), changes made in the classroom, in particular, adaptation of a physical environment to the needs of students are critical for their adaptation, overcoming of obstacles and well-being. It can be assumed that the creation of a supportive learning environment needs much more than a development of tolerant attitudes or a safe atmosphere - it is also important to focus on the formation of the physical environment.

The conducted analysis of scientific literature allows proposing that a material (physical) environment is a place which has a positive effect on learners (Kucinskas \& Poderienè, 2006), influences a learning progress, enhances motivation to participate in the learning process in an active and creative way (Grigaliūnienè, 2002).

After reviewing the results of research, it can be argued that though the concept of a material (physical) learning environment differs from the point of view of teachers and students, the differences, however, are not radical. Teachers, more than students, perceive the material (physical) learning environment as a factor in the development of aesthetic reflection (average rank - 238.90; $\chi 2$-21.842; $\mathrm{df}=2$; $\mathrm{p}-0.000$ ). 
Table 3 Differences in the teachers' and students' attitude toward the concept of a material (physical) learning environment

\begin{tabular}{|c|c|c|c|}
\hline $\begin{array}{c}\text { Variables of material (physical) learning } \\
\text { environment }\end{array}$ & Group & $\begin{array}{l}\text { Average } \\
\text { ranks }\end{array}$ & $\begin{array}{l}\text { Kruskal-Wallis } \\
\text { test results }\end{array}$ \\
\hline $\begin{array}{l}\text { Material (physical) learning environment is a } \\
\text { spatial structure of the learning and study area } \\
\text { (dimensions, purpose, microclimate, mobility, } \\
\text { transport, etc.). }\end{array}$ & $\frac{\text { Students }}{\text { Teachers }}$ & $\frac{213.18}{181.72}$ & $\begin{array}{l}\chi 2=6.536 \\
d f=2 ; p=0.034\end{array}$ \\
\hline $\begin{array}{l}\text { Material (physical) learning environment is } \\
\text { comfortable furniture, hardware, controls and } \\
\text { security measures }\end{array}$ & $\frac{\text { Students }}{\text { Teachers }}$ & $\frac{205.66}{187.17}$ & $\begin{array}{l}\chi 2=3.545 ; \quad \mathrm{df}=2 ; \\
\mathrm{p}=0.170\end{array}$ \\
\hline $\begin{array}{l}\text { Material (physical) learning environment is } \\
\text { ergonomic, clean and properly functioning } \\
\text { surrounding objects and operational means }\end{array}$ & $\frac{\text { Students }}{\text { Teachers }}$ & $\frac{236.58}{185.90}$ & $\begin{array}{l}\chi 2=7.190 ; \quad \mathrm{df}=2 ; \\
\mathrm{p}=0.27\end{array}$ \\
\hline $\begin{array}{l}\text { Material (physical) learning environment is a } \\
\text { factor in the development of aesthetic } \\
\text { reflection }\end{array}$ & $\frac{\text { Students }}{\text { Teachers }}$ & $\frac{175.48}{238.90}$ & $\begin{array}{l}\chi 2-21.842 ; d f=2 ; \\
p-0.000\end{array}$ \\
\hline $\begin{array}{l}\text { Material (physical) learning environment is an } \\
\text { ergonomic layout of workplaces, provision of } \\
\text { necessary learning and study facilities }\end{array}$ & $\frac{\text { Students }}{\text { Teachers }}$ & $\frac{196.35}{194.03}$ & $\begin{array}{l}\chi 2=1.112 ; \quad \mathrm{df}=2 ; \\
\mathrm{p}=0.573\end{array}$ \\
\hline
\end{tabular}

1.4. Differences in the attitude toward the concept of an intellectual learning environment

Table 4 Differences in the teachers' and students' attitude toward the concept of an intellectual learning environment

\begin{tabular}{|c|c|c|c|}
\hline $\begin{array}{c}\text { Variables of intellectual learning } \\
\text { environment }\end{array}$ & Group & $\begin{array}{l}\text { Average } \\
\text { ranks }\end{array}$ & $\begin{array}{l}\text { Kruskal-Wallis } \\
\text { test results }\end{array}$ \\
\hline $\begin{array}{l}\text { Intellectual learning environment is } \\
\text { informational systems that performs the task of } \\
\text { information retrieval }\end{array}$ & $\frac{\text { Students }}{\text { Teachers }}$ & $\begin{array}{l}202.02 \\
142.40 \\
\end{array}$ & $\begin{array}{l}\chi 2=12.664 ; \mathrm{df}=2 ; \\
\mathrm{p}=0.000\end{array}$ \\
\hline $\begin{array}{l}\text { Intellectual learning environment is } \\
\text { counselling systems }\end{array}$ & $\frac{\text { Students }}{\text { Teachers }}$ & $\frac{206.01}{162.39}$ & $\begin{array}{l}\chi 2=18.637 ; \mathrm{df}=2 ; \\
p=0.000\end{array}$ \\
\hline $\begin{array}{l}\text { Intellectual learning environment is training- } \\
\text { type systems that perform a didactic function in } \\
\text { formulating specific tasks for students, } \\
\text { recording their knowledge, identifying errors, } \\
\text { making recommendations, etc. }\end{array}$ & $\frac{\text { Students }}{\text { Teachers }}$ & $\frac{78.23}{229.25}$ & $\begin{array}{l}\chi 2=167.381 \\
\mathrm{df}=2 ; \mathrm{p}=0.000\end{array}$ \\
\hline $\begin{array}{l}\text { Intellectual learning environment is a } \\
\text { computer network- and other ICT-based system } \\
\text { for learning with the help of a supervisor }\end{array}$ & $\frac{\text { Students }}{\text { Teachers }}$ & $\frac{217.75}{130.94}$ & $\begin{array}{l}\chi 2=65.364 ; \mathrm{df}=2 ; \\
p=0.000\end{array}$ \\
\hline $\begin{array}{l}\text { Intellectual learning environment is the } \\
\text { Moodle system. }\end{array}$ & $\frac{\text { Students }}{\text { Teachers }}$ & $\begin{array}{l}220.34 \\
136.76 \\
\end{array}$ & $\begin{array}{l}\chi 2=17.037 ; \mathrm{df}=2 ; \\
p=0.000\end{array}$ \\
\hline
\end{tabular}


It is argued that an intellectual learning environment is recently construed as a virtual learning environment in which the entire educational process or individual parts of it take place (Priedys, 2012). An analysis of the research data suggests that students and teachers perceive the intellectual learning environment in a different way. Teachers treat it rather as training-type systems that perform a didactic function in formulating specific tasks for students, recording their knowledge, identifying errors, making recommendations, etc. (average rank - 229.25). Meanwhile, students understand the intellectual environment as the Moodle system (average rank - 220.76), as a computer network (average rank - 217.75), or as a counselling system (average rank - 206.01).

2. The attitude of teachers and students toward the accountability for creating and maintaining a supportive learning environment

The second question of research: What is the attitude of teachers and students toward the accountability for creating and maintaining a supportive learning environment and how does it differ?

To answer this question, the completed questionnaires of teachers and students were analysed using a nominal scale. By applying the Mann-Whitney U test, statistically significant differences in the estimates for creating and maintaining a supportive learning environment on the nominal scale have been identified (Mann-Whitney $\mathrm{U}=303.000, \mathrm{p}=0.000$ ): the average rank in the group of teachers tuned to be higher than in the group of students. The table below provides the differences between student and teacher estimates:

Table 5 Differences in the estimates for teachers' and students' attitude toward the accountability for creating and maintaining a supportive learning environment

\begin{tabular}{|l|l|l|l|}
\hline $\begin{array}{l}\text { Accountability for creating and } \\
\text { maintaining a supportive } \\
\text { learning environment }\end{array}$ & Students & Teachers & Chi-squared test results \\
\hline $\begin{array}{l}\text { A teacher is accountable } \\
\text { Students are accountable }\end{array}$ & $83.5 \%$ & $61.3 \%$ & $\chi 2=6.278 ; \mathrm{df}=1 ; \mathrm{p}=0.012$ \\
\hline $\begin{array}{l}\text { Teachers and students are } \\
\text { accountable }\end{array}$ & $32.9 \%$ & $83.9 \%$ & $\chi 2=23.195 ; \mathrm{df}=1 ; \mathrm{p}=0.000$ \\
\hline $\begin{array}{l}\text { University administration is } \\
\text { accountable }\end{array}$ & $24.1 \%$ & $83.9 \%$ & $\chi 2=32 ; \mathrm{df}=1 ; \mathrm{p}=0$. \\
\hline All actors are accountable & $25.3 \%$ & $96.8 \%$ & $\chi 2=45.852 ; \mathrm{df}=1 ; \mathrm{p}=0.000$ \\
\hline
\end{tabular}

As you can see in the table above, the study shows quite significant differences in estimates. As much as 83.5 percent of students believe that a teacher is responsible for creating and maintaining supportive learning environments. Though the teachers do not mind to assume accountability for the creation and maintenance of supportive learning environments $(61.3 \%$ of teachers think this way), they, however, believe that the accountability lies not 
only with them but with students (51.6 \%) and administration of the university (83.9 \%), as well. In other words, teachers believe that accountability for creating and maintaining supportive learning environments is shared among all the listed actors $(96.8 \%)$. The estimates presented by teachers, thus, do not match the students' estimates.

3. The attitude of teachers and students toward the elements of developing a supportive learning environment

The third question of research: What is the attitude of teachers and students toward the elements of developing a supportive learning environment and how does it differ? To answer this question, the completed questionnaires of teachers and students were analysed using a nominal scale. By applying the MannWhitney $U$ test, statistically significant differences in the estimates for the elements of developing a supportive learning environment on the nominal scale have been identified (Mann-Whitney $\mathrm{U}=596, \mathrm{p}=0.000$ ): the average rank in the group of teachers was higher than in the group of students. The table below provides the differences between student and teacher estimates:

Table 6 Differences in the estimates for teachers' and students' attitude toward the elements of developing a supportive learning environment

\begin{tabular}{|c|c|c|c|c|}
\hline $\begin{array}{c}\text { Elements of developing a supportive } \\
\text { learning environment }\end{array}$ & \multirow{2}{*}{\begin{tabular}{|l|} 
Students \\
$20.3 \%$ \\
\end{tabular}} & \multirow{2}{*}{$\begin{array}{l}\text { Teachers } \\
48.4 \%\end{array}$} & \multicolumn{2}{|c|}{$\begin{array}{l}\text { Chi-squared test } \\
\text { results }\end{array}$} \\
\hline $\begin{array}{l}\text { Providing students with all necessary } \\
\text { resources }\end{array}$ & & & $\begin{array}{l}\chi 2=8.707 \\
p=0.000\end{array}$ & $\mathrm{df}=1$ \\
\hline Support for the relevant learning excellence & $65.8 \%$ & $74.2 \%$ & $\begin{array}{l}\chi 2=3.091 \\
p=0.396\end{array}$ & $\mathrm{df}=1$ \\
\hline $\begin{array}{l}\text { Involvement of students in the organising } \\
\text { and planning of study and learning process }\end{array}$ & $44.3 \%$ & $58.1 \%$ & $\begin{array}{l}\chi 2=1.689 \\
p=0.194\end{array}$ & $\mathrm{df}=1$; \\
\hline Providing feedback at all times of studies & $44.3 \%$ & $83.9 \%$ & $\begin{array}{l}\chi 2=14.110 \\
p=0.00\end{array}$ & $\mathrm{df}=1$ \\
\hline $\begin{array}{l}\text { Providing freedom in activities and space for } \\
\text { a learner, recognition of individuality }\end{array}$ & $36.7 \%$ & $61.3 \%$ & $\begin{array}{l}\chi 2=5.470 \\
p=0.019\end{array}$ & $\mathrm{df}=1$ \\
\hline $\begin{array}{l}\text { Application of activating and interactive } \\
\text { didactic methods, andragogical dialogue and } \\
\text { andragogical approach, heterogeneity } \\
\text { management }\end{array}$ & $89.9 \%$ & $96.8 \%$ & $\begin{array}{l}\chi^{2}=1.411 \\
p=0.0235\end{array}$ & $\mathrm{df}=1$; \\
\hline $\begin{array}{l}\text { Provision of sufficient sources of informa- } \\
\text { tion, sharing of knowledge and experience }\end{array}$ & $60.8 \%$ & 83.9 & $\begin{array}{l}\chi 2=5.401 \\
p=0.020\end{array}$ & $\mathrm{df}=1$; \\
\hline $\begin{array}{l}\text { Providing timely advice, support / assistan- } \\
\text { ce to students in solving various problems }\end{array}$ & $67.1 \%$ & $90.3 \%$ & $\begin{array}{l}\chi 2=6.191 \\
p=0.013\end{array}$ & $\mathrm{df}=1$ \\
\hline $\begin{array}{l}\text { A content of the study subject is commu- } \\
\text { nicated in such a way that a learner is able } \\
\text { to understand, master it based on his/her } \\
\text { individual learning approach and style }\end{array}$ & $8.9 \%$ & $54.8 \%$ & $\begin{array}{l}\chi 2=27.591 \\
p=0.000\end{array}$ & $\mathrm{df}=1 ;$ \\
\hline
\end{tabular}


As the table above shows, one of the elements of developing a supportive learning environment has the smallest difference in estimates (Application of activating and interactive didactic methods: student estimates - $89.9 \%$, teachers - $96.8 \%$ ). The element of creating a supportive learning environment, such as Providing students with all necessary resources (student estimates $20.3 \%$, teachers - $48.4 \%$ ), is not a priority for students or teachers. Quite surprisingly, that less than half of the students participating in the survey were in favour of Providing freedom in activities and space for a learner - $36.7 \%$. Whereas $61.3 \%$ of teachers would like to apply this element in creating a supportive learning environment. This fact is presumably associated with inadequate independent behaviour of students. A small proportion of students and just over half of teachers opted for the element $A$ content of the study subject is communicated in such a way that a learner is able to understand, to master it based on his/her individual learning approach and style (students - $8.9 \%$, teachers $-54.8 \%$ ). It is assumed that the above estimates relate to the lack of knowledge in andragogy.

The research findings may relate to the studies conducted by $\mathrm{B}$. Jatkauskienè $(2013 ;$ 2014), G. Tolutienè (2013), other studies, with the basic concepts and ideas essentially coinciding with the results of the current research. The aforementioned authors emphasise the following elements of the development of the learning environment: mediation, respect for differences (Eggen \& Kauchak, 2013); problem solving, reflection, collaboration (Tolutiene, 2013); sense of safety (Muiji \& Reynalds 2011), application of andragogy approach, heterogeneity management, support/assistance in solving learning problems (Jatkauskienè, 2013; Jatkauskienè et al., 2014).

\section{The attitude of teachers and students toward mutual relations and harmonisation thereof in the creation of a supportive learning environment}

The fourth question of research: What is the attitude of teachers and students toward mutual relations and harmonisation thereof in the creation of a supportive learning environment, how does it differ? To answer this question, the completed questionnaires of teachers and students were analysed using a nominal scale. By applying the Mann-Whitney U test, statistically significant differences in the estimates have been identified (Mann-Whitney $U=921$, $\mathrm{p}=0.027$ ): the average rank in the group of teachers is higher than in the group of students. The table below provides the differences between student and teacher estimates: 
Jatkauskiene et al., 2018. A Supportive Learning Environment, the Creation of it as an Educational Factor: an Analysis of Teachers' and Students' Attitude

Table 7 Differences in the estimates for teachers' and students' attitude toward mutual relations and harmonisation thereof in the creation of a supportive learning environment

\begin{tabular}{|c|c|c|c|}
\hline $\begin{array}{l}\text { Factors of creation of a favourable } \\
\text { learning environment for the } \\
\text { harmonisation of mutual relations }\end{array}$ & Students & Teachers & $\begin{array}{l}\text { Chi-squared test } \\
\text { results }\end{array}$ \\
\hline $\begin{array}{l}\text { An educational environment supportive for } \\
\text { studies provides capacities to each student } \\
\text { and has a positive effect on the outcomes of } \\
\text { studies, mutual relations }\end{array}$ & $65.8 \%$ & $74.2 \%$ & $\begin{array}{l}\chi 2=0.719 ; \quad \mathrm{df}=1 ; \\
\mathrm{p}=0.396\end{array}$ \\
\hline $\begin{array}{l}\text { A psychological environment supportive for } \\
\text { studies stimulates student activity, critical } \\
\text { thinking, independence, communication and } \\
\text { collaboration }\end{array}$ & $63.3 \%$ & $80.6 \%$ & $\begin{array}{l}\chi 2=3.091 ; \quad \mathrm{df}=1 ; \\
\mathrm{p}=0.079\end{array}$ \\
\hline $\begin{array}{l}\text { A material (physical) environment } \\
\text { supportive for studies gives not only } \\
\text { aesthetic satisfaction or capability for } \\
\text { aesthetic reflection, but enhances the desire } \\
\text { to be in a group and with a group, too }\end{array}$ & $45.6 \%$ & $61.3 \%$ & $\begin{array}{l}\chi 2=2.201 ; \quad \mathrm{df}=1 ; \\
\mathrm{p}=0.138\end{array}$ \\
\hline $\begin{array}{l}\text { An intellectual environment supportive for } \\
\text { studies encourages student communication, } \\
\text { debates, team accomplishment of practical } \\
\text { tasks, implementation of joint projects, } \\
\text { sharing of experience, responsibility for } \\
\text { joint learning activities and mutual } \\
\text { relations, provides free access to information } \\
\text { and knowledge necessary for studies and } \\
\text { learning. }\end{array}$ & $78.5 \%$ & $83.9 \%$ & $\begin{array}{l}\chi 2=0.404 ; \quad \mathrm{df}=1 ; \\
p=0.525\end{array}$ \\
\hline
\end{tabular}

As can be seen from the data presented in the table above, most students and teachers (78.5 \% and $83.9 \%$ ) gave highest estimates for the intellectual environment supportive for studies which encourages student communication, debates, team accomplishment of practical tasks, implementation of joint projects, sharing of experience, responsibility for joint learning activities and mutual relations, provides free access to information and knowledge necessary for studies and learning. Hence, it can be assumed that the intellectual learning environment becomes the basic educational factor in the harmonisation of the group's interrelationships and achievement of better learning and learning outcomes. This assumption relates to the conceptual ideas of lifelong learning according to S. Neifach (2014: p. 20). The author emphasises the impact of a supportive intellectual learning environment on the harmonisation of interpersonal relations, as it becomes an inclusive field of innovation and experiment, an area for experiencing a new informational and communication culture. Within this area, social skills (teamwork skills, empathy, general design 
of activities, etc.) and learning-to-learn skills (self-learning, meta-cognitive skills, learning from mistakes and experiences, etc.) are being developed. The virtual intellectual learning environment is characterised by emerging new ways of learning that are specially designed for a learner of today; they are very intense, constructive, motivating and promoting excellence (Neifach, 2014: p. 21). The virtual environment is a space for learning by combining time and context, a virtual merging with other people, sources of information, which sometimes grows into a real interaction on the academic and personal levels.

The research findings, in conjunction with theoretical assumptions, allow suggesting that the relationship between the harmonisation of interrelations within a group of learners and a supportive learning environment must be referred to as a student-centred learning strategy (Jonasen et al., 2012). Besides, authors of foreign studies (Strange et al., 2015; Tuit et al., 2016) outline the main means for harmonising a group's interrelationships though the creation of a supportive learning environment: partnership, mediation, assistance/support for the learner; a dynamic and open context of the learning environment; flexible learning opportunities.

A material (physical) environment supportive for studies, which gives not only aesthetic satisfaction or capability for aesthetic reflection, but enhances the desire to be in a group and with a group, too, received the lowest score (students - $45.6 \%$, teachers - $61.3 \%$ ). It can be presumed that the student and the teacher of today increasingly associate their activities and communication with a virtual world, a virtual environment of learning and studies.

\section{Conclusions}

1. Following the analysis of scientific literature, it has been found that the concept of a learning environment is multidimensional, yet, the use of it in scientific discourse is sufficiently substantiated. Implementation of the concept of lifelong learning encourages both individual and group learning. In this connection, there emerge interpersonal relations within the group of learners and aspects of harmonisation thereof while creating a supportive learning environment.

2. Results of the empirical research allow arguing that the main hypothesis of the research - a supportive learning environment, the creation of it can be one of the main educational factors for the harmonisation of mutual relations in the group of learners and for the outcomes of studies and learning - is hereby validated.

3. The empirical study shows that teachers and students have quite a clear understanding of the concept of learning environments, however, both groups under study (teachers and students) construe various learning 
environments, elements of their creation, accountability of actors for creating and maintaining the environments in a different way.

4. It has been found that significantly more than half of students think that a teacher is accountable for creating and maintaining a supportive learning environment. Though the teachers do not mind to assume accountability, they, however, believe that the accountability lies not only with them but with students (51.6 \%) and administration of the university (83.9\%), as well.

5. When trying to find answers to the third question of research (what is the attitude of teachers and students toward the elements of developing a supportive learning environment and how does it differ), the attitude of teachers and students should be stressed to differ considerably. Quite surprisingly, that less than half of the students participating in the survey choose providing freedom in activities and space for a learner. Whereas, $61.3 \%$ of teachers are willing to apply this element in creating a supportive learning environment. This fact is presumably associated with inadequate independent behaviour of students. However, it is worth noting that most students and teachers speak for active and interactive didactic approaches to create a supportive learning environment.

6. The attitudes of teachers and students with regard to mutual relations and harmonisation thereof in creating a supportive learning environment differ in terms of estimates as well. An average rank in the group of teachers is higher than in the group of students. However, it is worth noting that both groups highly value an intellectual virtual environment of learning. Hence, it can be assumed that the intellectual virtual learning environment becomes the major educational factor for better achievements of learning and studies and even better interpersonal relationships. It should be also noted that other learning environments (educational, psychological, material (physical)) have been found to have an effect not only on student interrelationships, but on learning outcomes, student activity, critical thinking, independence, communication, collaboration, development of aesthetic reflection skills and etc., too. Thus, in spite of some differences in attitudes of teachers and students, both groups of respondents acknowledge the fact that a learning environment has an educational effect on interrelationships of students, outcomes of learning and studies.

7. It has to be assumed that observations made in this research can be used in the teaching practice so as to better understand contemporary students, relationships between teachers and students, as well as the formation of students' positive attitudes toward learning activities and communication.

8. Future directions for the research - further studies shall be aimed to find the means by which the teachers are able to build supportive learning 
environments in pursuing harmonisation of interrelations within a group of learners. Answers to the following questions will be sought: can means such as partnership, mediation, support / assistance, mentoring, leadership, socio-cognitive conflict solving, educational supervision, counselling, etc. be applied in creating supportive learning environments and harmonising interrelations within a group of learners. It is understood that further studies will attempt to identify which of the above means are particularly effective and function as an educational factor in learning, in pursuance of interrelationship coherence and high learning outcomes.

\section{References}

Blandin, B. (2008). Les environnements d'apprentissage. Editions: L'Harmattan.

Brazdeikis, V. (2009). Informacinèmis ir komunikacinemis technologijomis papildytu edukacinių aplinkų kaita. Informacijos mokslai, 50, 57-63.

Bullard, J. (2016). Creating Environments for Learning: Birth to Age Eight. Publisher: Pearson.

De Kock, A., Sleegers, P., \& Voeten, J. M. (2004). New Learning and the Classification of Learning Environments in Secondary Education. Review of Educational Research, 74 (2), 141-170.

Dumont, H., Istance, D., \& Benavides, F. (Eds.) (2010). The Nature of learning. Using research to inspire practice. Paris: OECD Publishing.

Eggen, P., \& Kauchak, D. (2013). Educational psychology: windows on classroom. Boston: Pearson.

Fisher, D., Frey, N., Quaglia, R. J., Smith, D., \& Lande, L. L. (2017). Engagement by Design: Creating Learning Environments Where Students Thrive. Publisher: CL Cowin Literacy.

Grigaliūnaitè, G. (2002). Daiktinè aplinka kaip kasdieninio estetinès refleksijos ugdymofaktorius. Mokslo darbai, 61. Vilnius: Pedagogika, p. 59.

Guščinskienè, J. (2009). Organizacijų sociologija. Kaunas: Technologija.

Hung, J. L., \& Zhang, K. (2008). Revealing online Learning Behaviors and Activity Patternsand Making Predictions with Data Mining Techniques in Online teaching. Merlot Journal of Online Learning and Teaching, 426-437.

Joseph, N. M., Haynes, Ch., \& Cobb, F. (2015). Interrogating Whiteness and Relinquishing Power: White Faculty's Commitment to Racial Consciousness in STEM Classrooms (Social Justice Across Contexts in Education). Publisher: Peter Lang Inc., International Academic Publishers.

Jensen, E. (2009). Super teaching. Over 1000 practical strategies. California: Corwin Press.

Jatkauskienè, B., \& Andriekienè, R. M. (2013). Universiteto dèstytoju veiklos daugiafunkcionalumas profesionalizacijos kontekste. Klaipédos universiteto atvejis. Monografija. Klaipėda, Lithuania: Klaipėda University Press.

Jatkauskienė, B., Andiekienė, R. M., \& Trakšelys, K. (2014). Universiteto dèstytojų didaktinė veikla: reali praktika, problemos, poreikiai. Andragogika. Mokslo darbai. 1 (5). Klaipėda. Jonassen, D., Land, S., Thomas, M., Strange, C. C., Banning, J. H. (2012). Theoretical Foundations of Learning Environments 2nd Edition [online]. Retrieved from: https://www.amazon.com/Theoretical-Foundations-Learning-Environments- 
Jatkauskiene et al., 2018. A Supportive Learning Environment, the Creation of it as an Educational Factor: an Analysis of Teachers' and Students' Attitude

Susan/dp/0415894220.

Jucevičienè, P. (2010). Universiteto edukacine galia: atsakas $i$ XXI amžiaus iššūkius. Monografija. Kaunas: Technologija.

Kaklauskas, L., \& Kaklauskienė, D. (2012). Virtualios aplinkos priemonių panaudos studijoms lyginamoji analizè. Studijos šiuolaikinèje visuomenèje. Mokslo darbai, 3 (1), 119-12.

Kučinskas, V., \& Poderienè, G. (2006). Ugdymo aplinkos ergonomika. Klaipėda: Klaipėdos universiteto leidykla.

Lipinskienè, D. (2002). Edukacinè studenta igalinanti studijuoti aplinka. Daktaro disertacija (Socialiniai mokslai, edukologija). Kaunas: Kaunas University of Technolog.

Maslow, A. (1962). Toward a Psychology of Being. New York: Van Nostrand.

Mazalto, M. (2017). Concevoir des espaces scolaires pour le bien-être et la réussite. Publisher: Editions L'Harmattan.

Mercer, C. D., Mercer, A. R., \& Pullen, P. C. (2011). Teaching students with learning problems. Boston: Pearson.

Muijs, D., \& Reynolds, D. (2011). Effective teaching. Evidence and practice. Los Angeles, London: Sage.

Nilson, L., \& Goodson, L. A. (2017). Online Teaching at Its Best: Merging Instructional Design with Teaching and Learning Research. Publisher: Jossey-Bass.

Priedys, S. (2012). Duomenu tarybos metody taikymas suasmeninto elektroninio mokymoaplinkose. Daktaro disertacija. Technologijos mokslai, Informatikos inžinerija (07T). Vilnius: VU.

Rogers, C. (1969). Freedom to Learn. Columbus: Charles E. Merrill.

Rupšienè, L., \& Rutkienè, A. (2016). Edukacinis eksperimentas. Klaipėda: KU leidykla.

Strange, C. C., \& Bannig, J. H. (2015). Designing for Learning: Creating Campus Environments for Student Success (2nd Ed.) [online]. Retrieved from: https://www.amazon.com/

Teresevičienè, M. \& Gedvilienè, G. (2003). Mokymasis grupèse ir asmenybès kaita. Monografija. Kaunas: Vytauto Didžiojo universiteto leidykla.

Tolutienè, G. (2013). Andragoginè sąveika ir jos raiška mokymosi aplinkos aspektu: teorinė irempirinè dimensijos. Andragogika 1 (4). Klaipèda, 111-126.

Trakšelys, K., \& Martišauskienè, D. (2013). Bendravimas mokymosi aplinkoje. Andragogika 1 (4). Klaipèda, 128-138.

Tuitt, F., Haynes, Ch., Stewart, S., \& Patton, L. D. (2016). Race, Equity, and the Learning Environment: The Global Relevance of Critical and Inclusive Pedagogies in Higher Education. Publishing: Stylus, LLC. 